\title{
Pengajaran Menggunakan Peta Sejarah dan Brosur Melalui Model PAIKEM (Pembelajaran Aktif, Inovatif, Kreatif dan Menyenangkan ) bagi Guru di SMP PUTRA MAJU
}

\author{
Yusinta Tia Rusdiana ${ }^{\text {1) }}$, Heryati ${ }^{2)}$ \\ ${ }^{1,2)}$ Universitas Muhammadiyah Palembang \\ rusdianatia@yahoo.com
}

\begin{abstract}
ABSTRAK : Pembelajaran IPS di Sekolah Menengah Pertama (SMP), pada umumnya dirasa membosankan oleh sebagian besar siswa. IPS dianggap tidak menarik karena hanya berisi tahun-tahun, rentetan peristiwa dan kejadian, tokoh-tokoh, fakta-fakta kering. Kebanyakan guru-guru yang mengajar mata pelajaran IPS masih monoton, tidak memberikan contohcontoh faktual, serta tidak digunakannya media pembelajaran yang dapat meningkatkan motivasi dan ketertarikan siswa terhadap pelajaran ini. Oleh karenanya pelatihan pengajaran mengunakan peta sejarah beserta contoh brosur tempat wisata sejarah di kota Pakembang diharapkan dapat mendorong guru-guru di SMP Putra Maju dapat membuat dan mengembangkan media dan menggunakannya dalam proses pembelajaran sehingga diharapkan kegiatan pembelajaran IPS berubah menjadi lebih menarik dan bermakna.Para guru merasa antusias mengikuti kegiatan pengabdian ini yang ditunjukkan dengan keaktivan mereka dalam mengikuti pelatihan . Mereka juga menindaklanjuti dengan praktik model-model pembelajaran salah satunya model PAIKEM, contoh media daam pengejaran di kelas para guru saling berdiskusi serta berkonsultasi dengan tim pengabdi dalam pendampingan. Mereka menganggap kegiatan ini sangat penting untuk meningkatkan kompetensi mereka sebagai guru yang harus merancang dan melaksanakan kegiatan pedagogis. Pengajaran dengan mengunakan peta sejarah disertai brosur sejarah merupakan salah satu rangkaian kegiatan tersebut sehingga membantuk meningkatkan skill dan kompetensi mereka..
\end{abstract}

Kata Kunci: Pembelajaran IPS, Peta Sejarah, Model PAIKEM,

ABSTRACT: Social studies learning in junior high schools is generally felt to be boring by most students. IPS is considered unattractive because it only contains years, series of events and events, figures, dry facts. Most teachers who teach social studies subjects are still monotonous, do not provide factual examples, and do not use learning media that can increase student motivation and interest in this subject. Therefore teaching training using historical maps along with examples of historical tourist brochures in the city of Pakembang is expected to encourage teachers in Putra Maju Junior High School to create and develop media and use them in the learning process so that social studies learning activities are expected to turn out to be more interesting and meaningful. The teachers were enthusiastic about participating in this service activity which was shown by their activity in attending the training. They also followed up with the practice of learning models, one of which was the PAIKEM model, examples of media in the pursuit in class, the teachers discussed with each other and consulted with the service team in mentoring. They consider this activity very important to improve their competence as teachers who must design and implement pedagogical activities. Teaching by using a historical map accompanied by a historical brochure is one of a series of activities so as to help improve their skills and competencies.

Keywords: Social Studies Learning, History Map, PAIKEM Model 


\section{PENDAHULUAN}

Pendidikan IPS merupakan salah satu mata pelajaran yang dapat memberikan wawasan pengetahuan yang luas mengenai masyarakat lokal maupun global sehingga mampu hidup bersama-sama dengan masyarakat lainnya. untuk mencapai tujuan tersebut, sekolah dasar sebagai lembaga formal dapat mengembangkan dan melatih potensi diri siswa yang mampu melahirkan manusia yang handal, baik dalam bidang akademik maupun dalam aspek moralnya. Sayangnya pembelajaran IPS di sekolah menengah pertama (SMP), pada umumnya masih jauh dari yang diharapkan. IPS dianggap sebagai pelajaran yang membosankan. Bahkan ada anggapan bahwa mata pelajaran IPS mudah dipelajari dan tidak menarik karena hanya berisi tahun-tahun, rentetan peristiwa, kejadian, tokoh-tokoh, dan fakta-fakta kering lainnya. Kebanyakan guru yang mengajar mata pelajaran IPS masih monoton dalam menyampaikan materi sehingga tidak mampu menciptakan iklim pembelajaran yang dinamis dan atraktif. Di masyarakat muncul anggapan bahwa mengajar IPS dianggap mudah, karena bersingungan langsung dengan kehidupan sehari-hari, sehingga dalam prosesnya ada kesan menyepelekan. Image tentang pembelajaran IPS semakin negatif dengan kurangnya contoh-contoh kontekstual dalam penyampaian materi sehingga peristiwa atau fenomena yang dikaji tidak mempunyai kebermaknaan bagi siswa, padahal sebenarnya untuk mempelajari IPS diperlukan pemahaman yang lebih mendalam.

Akibat ketidakmenariknya penyampaian materi IPS, nilai siswa menjadi tidak terlalu bagus. Karena terkesan mudah dan sepele maka mata pelajaran IPS dikesampingkan sehingga nilai siswa cenderung rendah. Kondisi ini semakin diperparah dengan metode pengajaran yang masih mengandalkan ceramah, one-way communication, tidak tersedianya media dan ketidakmampuan membuat media, yang menyebabkan siswa menjadi cepat bosan dan tidak paham akan apa yang diajarkan. Apabila hal ini terjadi maka yang akan terjadi adalah pelajaran menjadi membosankan, siswa mengantuk, kurang perhatian dan materi yang disampaikan.

Salah satu indikator keberhasilan mutu proses dalam hasil belajar siswa, selain guru dapat mengembangkan materi, sumber pembelajaran, metode, strategi, evaluasi dan penggunaan media. Media pembelajaran merupakan bagian yang penting dalam menunjang pembelajaran. Menurut Sumaatmadja (1984 : 116), media merupakan alat ari segala benda yang digunakan untuk membantu proses belajar mengajar. Dilihat dari macamnya, media pembelajaran terdiri dari : gambar-gambar, foto, grafik, poster, papan planel, visual hingga benda asli seperti laboratorium, nara sumber, dsb. Demikian pula dengan media peta. Peta merupakan hasil potretan dari berbagai peristiwa/kejadian, objek yang dituangkan dalam bentuk gambar, garis, simbol-simbol, maupun gambaran dari objek tertentu. Peta dalam pembelajaran Pengetahuan Sosial berfungsi untuk penyampaian materi agar lebih mudah diterima siswa, sehingga dapat membantu kelancaran aktivitas dan efesiensi dalam mencapai tujuan materi pembelajaran. 
Media berasal dari bahasa Latin merupakan bentuk jamak dari medium, yang berarti perantara yang dipakai untuk menunjukkan alat komunikasi. Secara harfiah media diartikan sebagai pelantara atau pengantar pesan dari pengirim penerima pesan. Sumaatmadja (1980 : 117), mengemukakan media pengajaran secara keseluruhan adalah segala benda, dan alat yang digunakan untuk membantu pelaksanaan PBM IPS. Seperti : slide, epidiaskup, proyektor, peta, globe, grafik, diagram, potret, gambar, maket, diorama, film, tape recorder, vide tape recorder, radio dll, termasuk media pengajaran yang digunakan dalam proses belajar mengajar IPS. Untuk memperjelas pemahaman siswa terhadap materi yang sedang dipelajari, sebaiknya alat-alat tersebut dapat digunakan guru dan siswa.

Media sebagai sumber pembelajaran erat kaitannya dengan peran guru. Gurutidak cukup memiliki pengetahuan tentang media tetapi dituntut untul terampil memilih, menggunakan serta mengusahakan memilih media yang tepat, kalau memungkinkan guru memiliki kemampuan untuk merancang dan membuat media sendiri. Memilih dan menggunakan media, perlu memperhatikan aspek tujuan, materi, metode dan evaluasi. Pengguanaan media bukan semata-mata melaksanakan salah satu komponen pengajaran, tetapi dengan media benar-benar berguna untuk memudahkan penguasaan siswa dalam belajar.

Upaya untuk mencapai tujuan pembelajaran Pendidikan IPS, sangat terkait dengan kemampuan guru dalam memanfaatkan media yang tersedia untuk kebutuhan siswanya, siswa dilatih menjadi terampil dan penuh pengalaman dalam menggunakan media. Proses pembelajaran yang didukung oleh media secara lengkap dapat menumbuhkan motivasi siswa dalam belajar. Mengenai tujuan belajar dapat diwujudkan dalam bentuk:

1) Menjadikan anak-anak senang, bergembira dan riang dalam belajar;

2) Memperbaiki berpiki kreatif anak-anak, sifat keingintahuan, kerjasama, harga diri dan rasa percaya pada diri sendiri, khususnya dalam menghadapi kehidupan akademik;

3) Mengembangkan sikap positif anak-anak dalam belajar;

4) Mengembangkan afeksi dan kepekaan terhadap peristiwa-peristiwa yang terjadi di lingkungannya, khususnya perubahan yang terjadi dalam lingkungan sosial dan teknologi. (Sumantri, Permana : 1999 :21).

Belajar adalah proses perubahan tingkah laku individu yang relatif tetap sebagai hasil dari pengalaman, sedangkan pembelajaran merupakan upaya penataan lingkungan yang memberi nuansa agar program belajar tumbuh dan berkembang secara optimal. Peristiwa belajar yang disertai proses pembelajaran akan lebih terarah dan sistematis dibandingkan dengan belajar dari pengalaman dalam kehidupan sehari-hari semata yang dimana dalam prosesnya terdapat peran guru, bahan ajar dan lingkungan kondusif yang sengaja diciptakan. Dalam prosesnya terdapat interaksi antara guru dan siswa yang tercipta sebagai usaha dalam mendewasakan diri dalam aspek akal, moral maupun 
emosional, dengan kata lain guru dan siswa merupakan subjek yang memiliki kebebasan secara aktif yang memungkinkan keterlibatan mental siswa secara optimal dalam merealisasikan pengalaman belajar.

Pengalaman belajar siswa tidak didapat begitu saja diperlukan kemampuan guru dalam mengembangkan pengetahuan dasar yang dimiliki siswa, karena pada dasarnya setiap siswa telah memiliki pengetahuan sebagai hasil interaksinya dengan lingkungan.Untuk mengembangkannya dalam pembelajaran tentu diperlukan strategi, pendekatan, metode dan teknik yang dapat merangasang rasa keingintahuan siswa.Peningkatan kualitas pembelajaran perlu mengembangkan pendekatan pembelajaran yang mendorong siswa aktif, mampu berinovatif, serta kreatif sehingga efektif namun tetap menyenangkan sesuai dengan karakteristik siswa Sekolah Dasar agar tujuan pembelajaran dapat tercapai maka diperlukan strategi pembelajaran yang mendukung, diantaranya strategi kontruktivistik, cooperative learning, dan inquiry dapat dipilih dan dikembangkan sebagai alternatif.

\section{Penjabaran PAIKEM}

a) Aktif

Pembelajaran yang aktif berarti pembelajaran yang memerlukan keaktifan semua siswa dan guru secara fisik, mental, emosional, bahkan moral dan spiritual. Guru harus menciptakan suasana sedemikian rupa sehingga siswa aktif bertanya, membangun gagasan, dan melakukan kegiatan yang dapat memberikan pengalaman langsung, sehingga belajar merupakan proses aktif siswa dalam membangun pengetahuannya sendiri.

b) Inovatif

Pembelajaran inovatif dapat menyeimbangkan fungsi otak kiri dan kanan apabila dilakukan dengan cara mengintegrasikan media/alat bantu terutama yang berbasis teknologi baru/maju ke dalam proses pembelajaran tersebut. Sehingga, terjadi proses renovasi mental, di antaranya membangun rasa pecaya diri siswa. Penggunaan bahan pelajaran, software multimedia, dan microsoft power point merupakan salah satu alternatif.

c) Kreatif

Pembelajaran yang kreatif mengandung makna tidak sekedar melaksanakan dan menerapkan kurikulum.Dengan demikian ada kreativitas pengembangan kompetensi dan kreativitas dalam pelaksanaan pembelajaran di kelas termasuk pemanfaatan lingkungan sebagai sumber bahan dan sarana untuk belajar. Pembelajaran kreatif juga dimaksudkan agar guru menciptakan kegiatan belajar yang beragam sehingga memenuhi berbagai tingkat kemampuan siswa dan tipe serta gaya belajar siswa.

d) Efektif

Pembelajaran dapat dikatakan efektif (effective / berhasil guna) jika mencapai sasaran atau minimal mencapai kompetensi dasar yang telah ditetapkan. Di samping itu, 
yang juga penting adalah banyaknya pengalaman dan hal baru yang "didapat" siswa. Guru pun diharapkan memeroleh "pengalaman baru" sebagai hasil interaksi dua arah dengan siswanya.

e) Pembelajaran Menyenangkan

Pembelajaran yang menyenangkan adalah pembelajaran yang dapat dinikmati siswa. Siswa merasa nyaman, aman dan asyik.Perasaan yang mengasyikkan mengandung unsur inner motivation, yaitu dorongan keingintahuan yang disertai upaya mencari tahu sesuatu.

\section{Kerangka Pemecahan Masalah}

Permasalahan yang teridentifikasi adalah Urgensi penggunaan media dalam pembelajaran IPS khususnya pengunaan peta sejarah Selama ini guru jarang menggunakan media, karena di samping memerlukan waktu dan ketrampilan tertentu, juga dibutuhkan biaya yang tidak sedikit. Permasalahan semakin kompleks ketika sekolah harus menyediakan sarana pendukung yang harganya mahal seperti sound system, LCD, Screen, dan sebagainya.

Permasalahan lain adalah guru tidak bisa membuat media berupa peta sejarah atau brosur tempat- tempat bersejarah di kota Palembang, hal tersebut disebabkan karena tidak mempunyai kemampuan untuk itu khususnya bagi guru yang sudah usia lanjut. Sementara itu bagi guru yang masih muda, mayoritas hanya mengunakan media sederhana seperti kertas karton sederhana, sementara itu media peta sejarah belum sama sekali tersentuh/ dipergunakan, serta perlunya suatu model pembelajaran yang perlu di kembangkan yakni melalui model PAIKEM.

\section{Realisasi Pemecahan Masalah}

Realisasi pemecahan masalahnya adalah dilakukan pelatihan dan praktek pengajaran mengunakan peta sejarah bagi peserta didik, serta contoh brosur yang dapat menambah wawasan peserta didik khususnya tempat bersejarah di kota Palembang. Bagi guru- guru di SMP Putra Maju kiranya dapat memilih model pembelajaran yang tepat salah satunya model PAIKEM. Dengan adanya pengabdian masyarakat guru-guru dapat meningkatkan kompetensi mengajar dan terus mengembangkan model pembelajaran yang menyenangkan.

\section{METODE PELAKSANAAN}

Motode kegiatan yang dilakukan dalam kegiatan pengabdian adalah bentuk pelatihan adalah

1. Ceramah dan tanya jawab

Ceramah dilakukan sebagai salah satu bentuk pengenalan tentang kegiatan yang akan dilakukan pada umumnya, bagaimana kegiatan ini nanti berjalan, dan hal apa yang bisa peserta dapatkan dari kegiatan pengabdian kepada masyarakat ini. Kegiatan dilakukan dipadu dengan tanya jawab sebagai salah satu alternatif 
mendekatkan diri antara pengabdi dengan peserta, sekaligus agar peserta semakin paham tentang apa yang nantinya akan diajarkan.

2. Demontrasi

Kegiatan demontrasi bertujuan untuk memperlihatkan dan memperkenalkan pengajaran mengunakan media peta sejarah yang bisa digunakan untuk proses pembelajaran IPS disertai contoh brosur tempat bersejarah.

3. Praktek

Kegiatan praktek merupakan kegiatan menuangkan hasil tutorial dalam bentuk nyata, yaitu peserta dihadapkan pada praktek langsung, peserta juga diajarkan bagaimana pengajaran peta sejarah melalui model PAIKEM memadukan dengang materi dan mengolahnya sehingga menjadi media pembelajaran.

\section{PELAKSANAAN}

Adapun garis besar hasil pelaksanaan kegiatan pengabdian kepada masyarakat adalah sebagai berikut:

a. Kegiatan pengabdian didahului dengan survey untuk mengetahui prioritas dan kebutuhan guru untuk meningkatkan profesionalitasnya.

b. Pelatihan dilaksanakan di sekolah SMP Putra Maju kegiatan langsung dipimpin oleh Bapak Kepala Sekolah Bapak Drs. H. Sarwiji pada hari Kamis tanggal 12 Desember 2018. Kegiatan pelatihan dihadiri oleh 20 orang guru (semua peserta yang diundang hadir) dan peserta menunjukkan antusiasme cukup besar terhadap program pengabdian ini.

c. Materi pelatihan disampaikan secara langsung oleh tim pengabdian dibantu oleh 2 orang mahasiswa sebagai tim teknis.

d. Penggunaan media Pengajaran mengunakan peta sejarah di lingkungan pendidikan, khususnya sekolah tingkat SMP belum pernah dilakukan. Padahal media dengan mengunakan peta ini sangat mudah pembuatannya dan tidak memerlukan biaya mahal. Akan tetapi peralatan yang mendukung penggunaan media pembelajaran (khususnya LCD) memang masih terbatas, dimana belum semua kelas dilengkapi dengan LCD. Faktor lain yang menyebabkan belum banyaknya guru-guru yang memanfaatkan media pengajaran mengunakan peta adalah ketidakmauan dan ketidakmampuan guru untuk membuat dan mengembangkan media tersebut.

e. Kemampuan peserta pelatihan dalam penguasaan materi dengan mengunakan media peta dan brosur dan praktek mengajar dengan mengunakan model PAIKEM cukup baik.

f. Program pengabdian berhasil mendorong guru-guru untuk mengunakan media pembelelajaran salah satunya mengunakan peta sejarah yang disertai brosur tempat bersejarah di kota Palembang.

g. Program pengabdian ini berhasil agar setiap guru dapat mengunakan model pembelajaran yang menyenangkan salah satunya adalah model PAIKEM. 


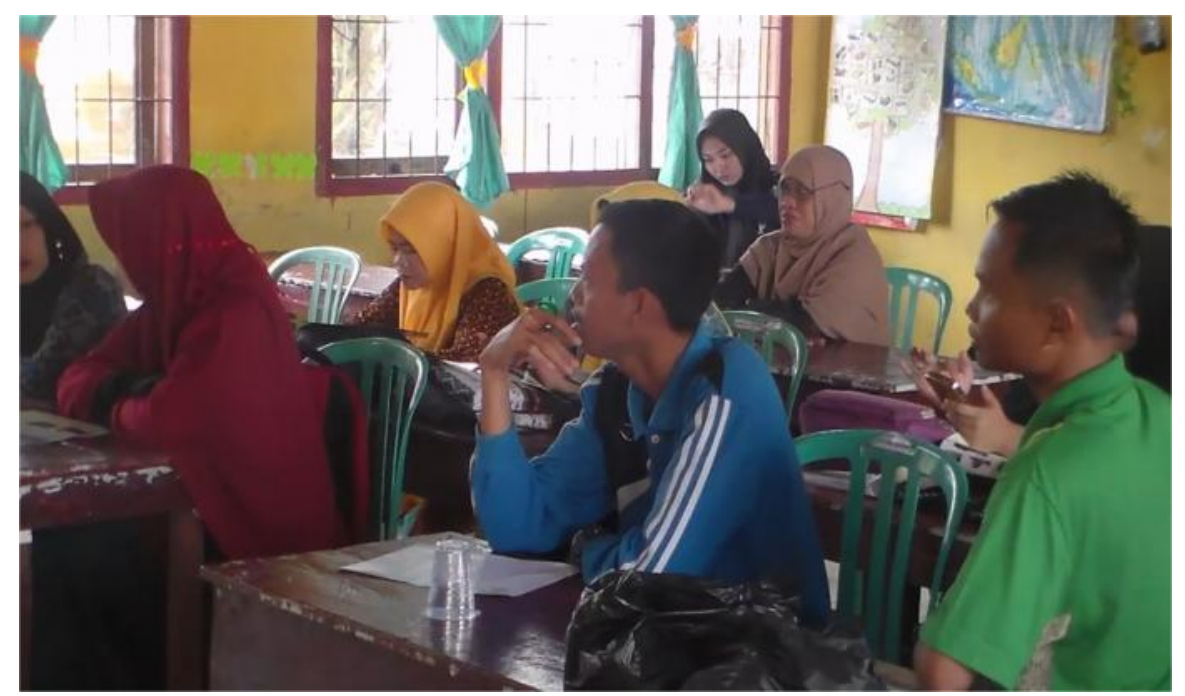

Gambar 1. Persiapan sebelum pelatihan dimulai

\section{HASIL DAN LUARAN}

Kegiatan pelaksanan pegabdian masyarakat di sekolah SMP Putra Maju. pelatihan pengajaran mengunakan media peta sejarah dirasakan mempunyai manfaat yang besar bagi guru IPS. Mereka menyadari bahwa pembelajaran IPS harus disajikan dengan menarik sehingga membutuhkan media yang dinamis dan dapat menarik perhatian siswa. Sisi lain yang perlu diperhitungkan adalah aspek kemudahan, karena media terus mengalami penyempurnaan dari waktu ke waktu sehingga harus memungkinkan untuk dirubah setiap saat.

Guru-guru umumnya menyambut gembira dengan adanya pelatihan ini yang dibuktikan dengan antusiasme mereka untuk bertanya dalam sesi ceramah. Mereka menanyakan apa saja hal-hal yang mereka hadapi ketika berusaha membuat dan mengembangkan media pembelajaran, mulai dari kendala teknis sampai finansial dan waktu yang terbatas. Dalam hal ini tim pengabdi harus dapat memotivasi guru untuk mengembangkan media meskipun dengan merelakan pengorbanan baik waktu, tenaga maupun keuangan. 


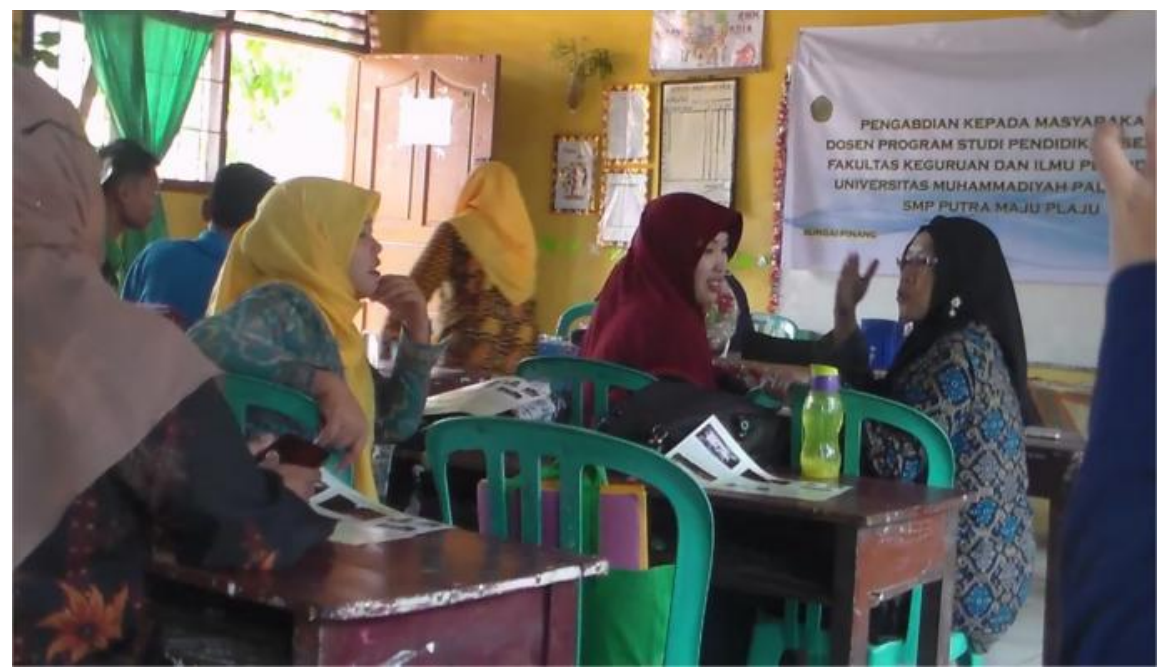

\section{Gambar 2. Guru-guru sedang berdiskusi mengenai Media Pembelajaran}

Setelah guru-guru memahami media pengajaran mengunakan peta sejarah dan brosur berupa tempat-tempat bersejarah di kota palembang, materi dilanjutkan dengan praktik mengunakan model pembelajaran PAIKEM. PAIKEM adalah singkatan dari Pembelajaran Aktif, Inovatif, Kreatif, Efektif, dan Menyenangkan. Aktif dimaksudkan bahwa dalam proses pembelajaran guru harus menciptakan suasana sedemikian rupa sehingga siswa aktif bertanya, mempertanyakan, dan mengemukakan gagasan. Pembelajaran inovatif bisa mengadaptasi dari model pembelajaran yang menyenangkan. Learning is fun merupakan kunci yang diterapkan dalam pembelajaran inovatif. Jika siswa sudah menanamkan hal ini di pikirannya tidak akan ada lagi siswa yang pasif di kelas, perasaan tertekan dengan tenggat waktu tugas, kemungkinan kegagalan, keterbatasan pilihan, dan tentu saja rasa bosan.

Secara garis besar, PAIKEM dalam kegiatan guru mengajar dapat digambarkan sebagai berikut:

1. Siswa terlibat dalam berbagai kegiatan yang mengembangkan pemahaman dan kemampuan mereka dengan penekanan pada belajar melalui berbuat.

2. Guru menggunakan berbagai alat bantu dan berbagai cara dalam membangkitkan semangat, termasuk menggunakan lingkungan sebagai sumber belajar untuk menjadikan pembelajaran menarik, menyenangkan, dan cocok bagi siswa.

3. Guru mengatur kelas dengan memajang buku-buku dan bahan belajar yang lebih menarik dan menyediakan "pojok baca".

4. Guru menerapkan cara mengajar yang lebih kooperatif dan interaktif, termasuk cara belajar kelompok.

5. Guru mendorong siswa untuk menemukan caranya sendiri dalam pemecahan suatu masalah, untuk mengungkapkan gagasannya, dan melibatkam siswa dalam 
menciptakan lingkungan sekolahnya.

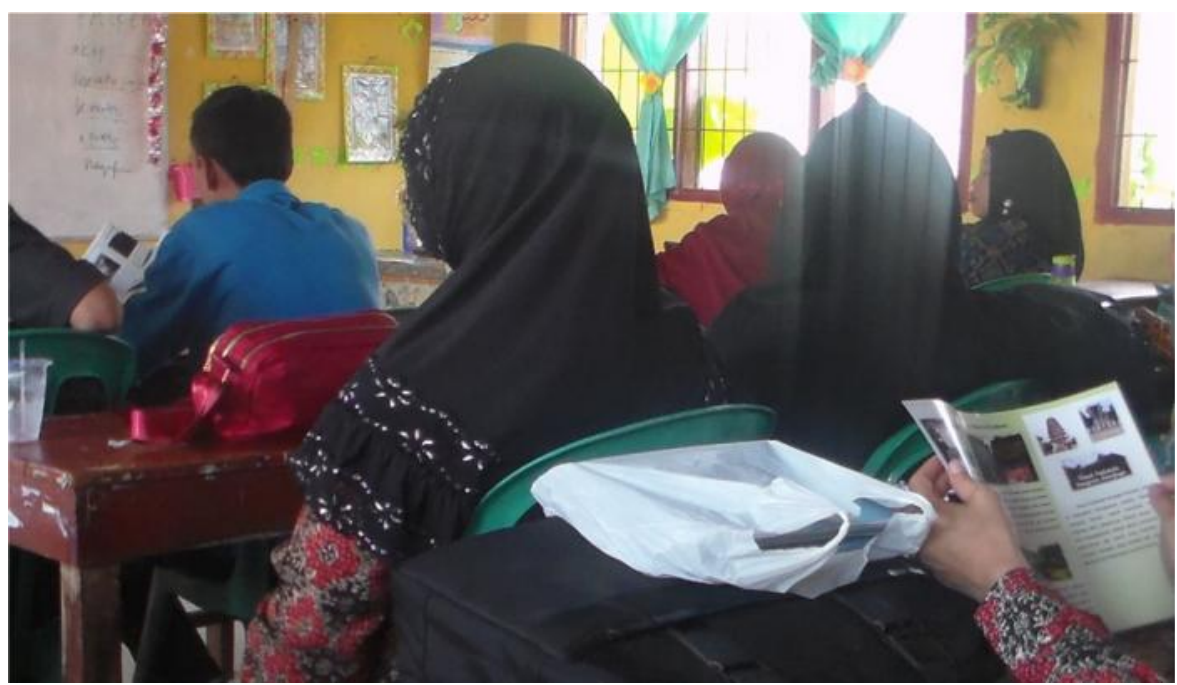

\section{Gambar 3. Guru- guru sedang menyimak model Pembelajaran PAIKEM}

Hasil kegiatan pengabdian secara garis besar dapat dilihat berdasarkan beberapa komponen berikut:

a. Keberhasilan target jumlah peserta pelatihan

Keberhasilan target jumlah peserta pelatihan dapat dikatakan sangat baik. Target jumlah peserta pelatihan sebanyak 20 orang dan dalam pelaksanaan pengabdian dapat hadir sebanyak 20 orang (100\%). Hal ini didukung peran kepala sekolah yang telah memberikan izin dan dukungan kepada guru-guru dimulai dari persiapan, ruangan kelas, dan peralatannya.

b. Ketercapaian tujuan pelatihan

Ketercapaian tujuan pelatihan dapat dikatakan baik (85\%). Kegiatan pengabdian ini berhasil mendorong guru-guru untuk mengunakan media pembelelajaran salah satunya mengunakan peta sejarah yang disertai brosur tempat bersejarah di kota Palembang serta guru dapat mengunakan model pembelajaran yang menyenangkan salah satunya adalah model PAIKEM.

c. Ketercapaian target materi yang telah direncanakan

Ketercapaian target materi yang telah direncanakan dapat dikatakan baik (80\%). Semua materi pelatihan dapat disampaikan secara keseluruhan meskipun tidak secara detil karena keterbatasan waktu. Materi pelatihan yang telah disampaikan adalah ceramah dan tanya jawab demonstrasi memperlihatkan dan memperkenalkan pengajaran mengunakan media peta sejarah yang bisa digunakan untuk proses pembelajaran IPS disertai contoh brosur tempat bersejarah. Serta praktek langsung guru- guru diajarkan bagaimana pengajaran peta sejarah melalui model PAIKEM. 
d. Kemampuan peserta dalam penguasaan materi

Kemampuan peserta dalam penguasaan materi dapat dikatakan baik (80\%). Hal ini didukung penggunaan metode ceramah dan tanya jawab, demonstrasi, praktek langsung untuk meningkatkan kemampuan peserta pelatihan dalam menyerap materi yang disampaikan oleh nara sumber. Secara keseluruhan kegiatan pelatihan pengajaran mengunakan peta sejarah disertai contoh brosur wisata sejarah di Palembang dinilai berhasil. Keberhasilan ini selain diukur dari keempat komponen di atas, juga dapat dilihat dari kepuasan peserta setelah mengikuti kegiatan pelatihan. Manfaat yang dapat diperoleh para peserta pelatihan adalah Meningkatkan kompetensi pedagogis guru serta menambah pemahaman tentang pentingnya media dalam proses pembelajaran dan mengembangkan guru dalam merancang suatu model pembelajaran salah satunya model PAIKEM.

\section{KESIMPULAN}

Berdasarkan uraian dalam pembahasan, maka dapat disimpulkan sebagai berikut:

a. Pelatihan pengajaran mengunakan peta sejarah dan brosur tempat wisata sejarah di palembang sangatlah efektif untuk di gunakan guru-guru dalam mengembangkan media pembelajaran. Dengan adanya media pembelajaran sangatlah mempermudah guru dalam menyampaikan materi.

b. Kegiatan pengabdian pengajaran peta melalui model pembelajaran PAIKEM dapat memdorong guru-guru dalam mengembangkan kompetensi mengajar dikelas. Sehingga peserta didik tidak hanya aktif tetapi belajar juga harus menyenangkan.

\section{DAFTAR PUSTAKA.}

1999. Studi Geografi. Suatu Pendekatan dan Analisis Keruangan

Sumaatmadja, N. 1984. Metodologi Pengajaran IPS. Bandung. Penerbit Alumni.

Sumantri, Permana. 1999. Strategi Belajar Mengajar. Depdikbud. Dirjen Dikti. PPGSD, IBRD: Loan 4394- IND.

Somantri, N. 1996. Menggagas Pembaharuan Pendidikan IPS. PPS dan FPIPS UPI Bandung: Remaja Rosakarya. 